\title{
Applications of Radiofrequency in Ent
}

\section{Neha Shah,}

St.Elizabeth, Dalvi and Cumballa Hill hospitals Mumbai,India

Corresponding author: Neha Shah, St.Elizabeth, Dalvi and Cumballa Hill hospitals Mumbai,India.

Received Date: February 25, 2020; Accepted Date: March 05, 2020; Published Date: March $16,2020$.

Citation: Neha Shah. (2020) Applications of Radiofrequency in Ent. Journal of Clinical Otorhinolaryngology, 2(1): Doi: 10.31579/ 2692-9562/003

Copyright: ( ) 2020.Shah N, This is an open-access article distributed under the terms of the Creative Commons Attribution License, which permits unrestricted use, distribution, and reproduction in any medium, provided the original author and source are credited.

\begin{abstract}
Radiofrequency proves to be a useful tool for snoring and obstructive sleep apnoea cases. Its advantages include relative precision in incision making, relatively bloodless fields if used appropriately, decrease postoperative pain and excellent healing with fibrosis which aids in stiffening tissues.

Radiofrequency is high frequency alternating current used to ablate (cut/coagulate) tissues. Radiofrequency ablation treatment can be applied to nasal turbinates, soft palate, tongue base, tonsils etc and it can be used in various surgeries in the cutting mode to improve obstructive sleep disordered breathing.

Keywords: Radiofrequency, sleep disordered breathing, precision
\end{abstract}

Objectives / Aim: Was to assess efficacy of Radiofrequency as a tool for procedures for snoring - sleep apnoea. The parameters assessed were: postoperative pain-scores, intra and postoperative blood loss, reduction in subjective snoring sounds by patient and partner and reduction in AHI postoperatively.

Methods: The procedures were carried out over a period of three years. All cases that came to us with complaints of snoring, difficulty in breathing, and sleep disturbances at the various hospitals were included in the study. A total-of around 25 cases were studied. A thorough history, clinical examination in all and where feasible, flexible endoscopy and sleep study were carried out. Radiofrequency Sutter BM 7180 machine was used to treats cases over the time period. The power settings used varied from 2-6 in the cutting and coagulation mode. Procedures were carried out under local or general anaesthesia with oral intubation and a throat pack.

\section{Radiofrequency Tonsillectomy}

Exposing the tonsil on either side, the to-bite Radiofrequency forceps or the $\mathrm{Rf}$ needle was used to incise/open the plane for tonsillar dissection.Dissection was carried out with the same, achieving haemostasis at the same time. If adequately carried out, bleeding was minimal and pain scores were low post operatively.Fossa deepens and stiffens post operatively. Rf setting: 2-3 in cutting mode and 5-6 in coagulation mode.

\section{Radiofrequency Adenoidectomy}

Can be performed after retracting lower edge of the palate with tongue depressors or tourniquets and coagulating the adenoid with bipolar forceps. Lower edge of the adenoid can be also be dissected using $\mathrm{Rf}$ needle or ball point. Bleeding is negligible and wound heals well. No case of post- operative haemorrhage was encountered. Ideal for recurrent adenoids. Rf setting: 5-6 in the coagulation mode.

\section{Radiofrequency Somnoplasty}

It is temperature controlled Rf volumetric tissue reduction of the palate in order to stiffen or scar the soft palate. The Sutter Rf bipolar probe is used to deliver energy to the soft palate at various points. Blanching has to be avoided. The subsequent stiffening occurred over 6 weeks. Procedures can be done as office procedures and under local anaesthesia, and involved no bleeding and pain scores were very low.Subjective decrease in snoring was achieved even in 1 sitting.

\section{Radio Frequency Tongue Base Reduction}

It is temperature controlled volumetric reduction of the tongue base achieved by giving Rf energy to multiple sites of posterior tongue base with Sutter RF bipolar probes.Three sittings of application gives a significant reduction in tongue base tissue. There was no incidence of tongue base oedema or infection. The procedure can be carried out under local or general anaesthesia.

Radio frequency UP3 ( $\mathrm{Rf}$ assisted uvulopalatopharyngoplasty) is achieved by uvular and lateral cuts with $\mathrm{Rf}$ in cutting mode and tonsillectomy with pillar suturing. The post-operative widening, contracture/stiffening helps in achieving a good result.

RAUP ( $\mathrm{Rf}$ assisted uvulopalatoplasty) for snoring is done by uvular and lateral cuts, and redefining the posterior pillars.Tonsillectomy maybe combined .It achieves its result due to removal of the redundant mucosa and subsequent healing with fibrosis. Subjective decrease in snoring is achieved in most patients. Rf is used in cutting mode. 


\section{Results}

\begin{tabular}{|l|l|l|l|l|}
\hline Procedures & No: of cases & $\begin{array}{l}\text { Pain scores } \\
(0-5)\end{array}$ & Intra op bleeding(ml) & Post op bleeding \\
\hline $\begin{array}{l}\text { RF } \\
\text { SOMNOPLASTY/PALATE }\end{array}$ & 5 & $1-4$ & nil & nil \\
\hline RAUP & 6 & $3-4$ & negligible & nil \\
\hline RF TONSILS & 6 & $4-5$ & $3-10 \mathrm{ml}, 3-$ nil & nil \\
\hline RFUP3 & 2 & $4-5$ & nil & nil \\
\hline RF TONGUE BASE & 4 & $0-1$ & Nil & nil \\
\hline RF ADENOIDS & 4 & 0 & Nil & nil \\
\hline
\end{tabular}

\section{Discussion}

Of the 27 patients who underwent some form of treatment with radiofrequency,

Of the 5 somnoplasty patients, 2 patients got a pain score of 4 and 3 patients 0-1.

RAUP patients had a varied score from 1-4.

RF adenoidectomy was relatively pain free

RF Tonsillectomy was between 4 and 5 .

RF tongue base had very low pain scores

There was no post bleeding in any of the cases. Intra operative bleeding was encountered in tonsillectomy cases when RF was used in the cutting mode. Rf somnoplasty, 1 sitting can give a reduction in snoring by 50$70 \%$. RF in cutting mode if used inappropriately can give rise to bleeding otherwise not.

\section{Conclusion}

Radiofrequency appears to be an efficient tool for snoring sleep apnoea -Ability to cut fast and with precision and maintain a relatively blood less field
-Ability to cut and coagulate

-Decrease intraoperative blood loss

-Induces fibrosis and stiffening of tissue

\section{Other advantages include}

1. The instrument/unit appears dynamic with a good feel

2. Procedures can be performed under local/general anaesthesia

3. Instruments are autoclavable/recurring cost is low

4. Machine is ambulatory

5. Minimally invasive

\section{References}

1. Steward DL. (2006). Methods and outcomes of Radiofrequency ablation for obstructive sleep apnoea.Dept of otolaryngology, head and neck surgery, University of Cincinnati medical centre, Cincinnati Ohio.

2. Pang KP, Blanchard AR, Terries DJ. Surgical treatment of sleep disordered breathing. Department of otolaryngology, Tan Tock Sengh hospital Singapore and dept. of otolaryngology,Medical college of Georgia, Augusta, Georgia,USA.

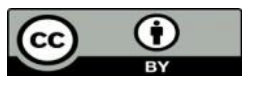

This work is licensed under Creative Commons Attribution 4.0 License

\section{To Submit Your Article Click Here: Submit Manuscript}

DOI: $10.31579 / \mathrm{jco} .2020 / 003$
Ready to submit your research? Choose Auctores and benefit from:

* fast, convenient online submission

* rigorous peer review by experienced research in your field

* rapid publication on acceptance

* authors retain copyrights

* unique DOI for allarticles

* immediate, unrestricted online access

At Auctores, research is always in progress.

Learn more www.auctoresonline.org/journals/journal-of-clinicalotorhinolaryngology 